\title{
PHYSICOCHEMICAL CHARACTERISTICS OF MARINE WATER AT JETTY POINTS ALONG IKORODU-LAGOS ISLAND, LAGOS STATE, SOUTH-WEST NIGERIA
}

A.T. AINA

(Received 11 August 2016; Revision Accepted 18 November 2016)

\begin{abstract}
Marine water is a vital component to the development of Nigerian economy. Human activities at jetties have potential impact on marine water quality in the study area. The present study investigated the Physicochemical characteristics of marine water at nine jetties along Ikorodu-Lagos Island, Lagos state, South-West Nigeria. Water samples were collected and analysed for Temperature, $\mathrm{pH}$, Conductivity, Total Dissolved Solids(TDS), Colour, Dissolved Oxygen(DO), Biochemical Oxygen Demand(BOD), Nitrate, Cyanuric acid, Chromium, Copper, Iron, Manganese, Sulphate and Phosphate. Results showed the range of each of the parameters tested as: Temperature 20.10 to $22.90^{\circ} \mathrm{C}$, pH 6.66 to 7.34, Conductivity 196 to $5646 \mu \mathrm{hoS} / \mathrm{cm}$, Total Dissolved Solids(TDS) 125 to 699mg/l, Colour 15 to $98 \mathrm{PtCo}$, Dissolved Oxygen(DO) 6.62 to $8.46 \mathrm{mg} / \mathrm{l}$, Biochemical Oxygen Demand(BOD) 98 to $214 \mathrm{mg} / \mathrm{l}$, Nitrate 0.00 to $5.2 \mathrm{mg} / \mathrm{l}$., Cyanuric acid 0.00 to $5.2 \mathrm{mg} / \mathrm{l}$, Chromium 0.00 to $0.12 \mathrm{mg} / \mathrm{l}$, Copper 0.29 to $1.17 \mathrm{mg} / \mathrm{l}$, Iron 0.22 to $1.10 \mathrm{mg} / \mathrm{l}$, Manganese 0.01 to $0.79 \mathrm{mg} / \mathrm{l}$, Sulphate 20.00 to $65.00 \mathrm{mg} / \mathrm{l}$ and Phosphate 0.08 to $1.86 \mathrm{mg} / \mathrm{l}$. The values of most of the parameters studied were within the acceptable limits specified by WHO/FMnev standards. However, BOD values were beyond limits which could be indicative of direct waste disposal into the water at the jetties.
\end{abstract}

KEYWORDS: Jetty, WHO/FMnev standard, water quality

\section{INTRODUCTION}

Pollution of the Lagos lagoon constitutes one of the environmental problems in Lagos metropolis; it receives inputs of domestic sewage, industrial waste waters, saw dust and particulate wood wastes, petroleum hydrocarbons, cooling water from a thermal power station and emissions from automobile exhaust (Okoye et al., 2010). Garbage thrown by the public into the sea affects the quality of the sea water. Limited studies have been carried out on rising trend of solid waste costal dumpsites and its effects on our water bodies (Amaeze et al. 2012).

Jetties are found in many coastal regions around the world, especially at water fronts where ships, boats, canoes and other marine transport facilities are docked for the transportation of humans, goods and services across water bodies. Marine transportation is becoming more acceptable in Lagos state because of the heavy traffic gridlocks on major roads. Jetties are constructed using wood or blocks and cement at the banks of the rivers to enable commuters embark and disembark the boats and at these points, commuters discard empty cans, sachets and polyethylene bags and bottles of drinks into the river.

The study evaluates the Physicochemical characteristics of marine water at jetties from IkoroduLagos Island, South-west Nigeria using the compliance level of World Health Organization Federal Ministry of Environment Standards (WHO/ FMnev, 2003).

\section{MATERIALS AND METHODS}

\section{Sampling Area}

The study was carried out at nine jetties (Lekki, Bayeku, Offin, Addax, Falomo, Metro, Origin, CMS and Ebutero) along Ikorodu to Lagos Island, Lagos State. These areas are fishing and marketing areas with unauthorized waste dump sites. CMS and Ebutero jetties witness lots of other activities resulting from the large number of people patronizing the popular Eko market located around the jetties. The other jetties have minimal human activities but for loading and disengaging passengers. The average temperature in Lagos State is $28.1-32.7^{\circ} \mathrm{C}$ (High) and $21.7-23.8^{\circ} \mathrm{C}$ (Low) and rainfall ranges between $19-312 \mathrm{~mm}$ (Lagos state Government, 2016).

\section{Sampling}

Thirty-six water samples were collected from nine jetties (Lekki, Bayeku, Offin, Addax, Falomo, Metro, Origin, CMS and Ebutero) along Ikorodu-Lagos Island in Lagos State, South-West Nigeria. Four composite grab samples were obtained randomly at $100 \mathrm{~m}$ interval at each location using plastic hydrobios water sampler. Samples were collected in polyethylene bottles and taken to the Quality control Laboratory, University of Lagos, Akoka, for analysis. Prior to collection, containers were prewashed with detergents, rinsed with distilled water, soaked with absolute alcohol and allowed to dry.

A.T. Aina, Institute of Maritime Studies \& Principal Quality Control Officer, University of Lagos Akoka, Lagos State, Nigeria. 

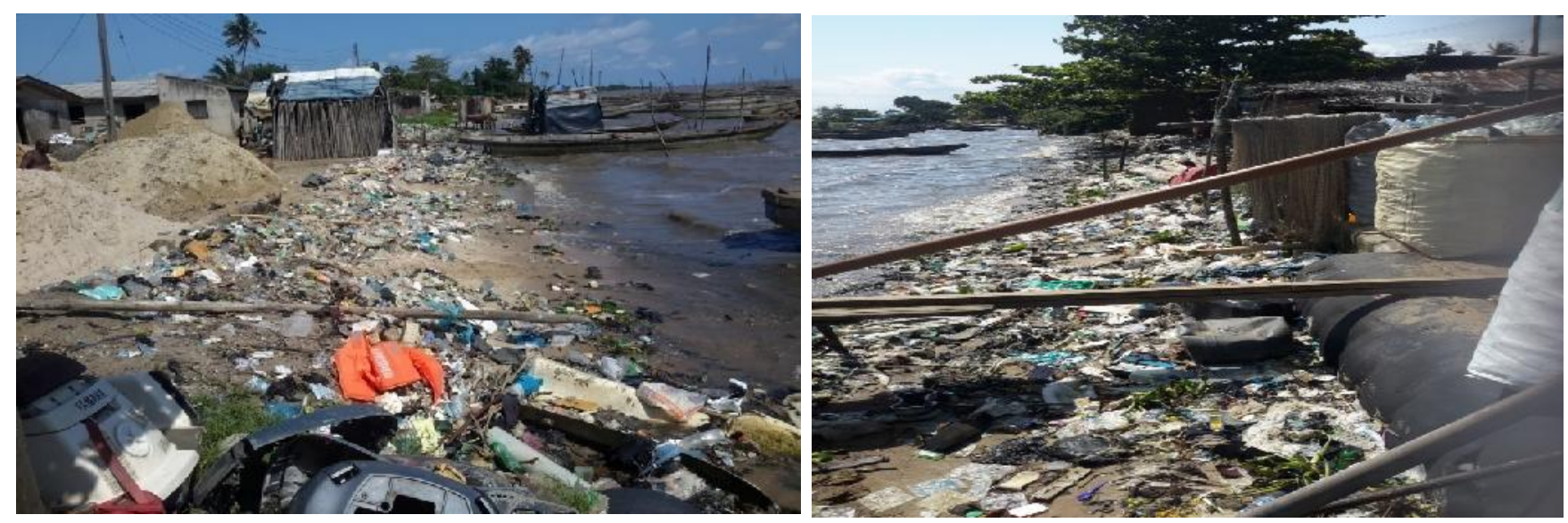

Figure 1: Sectional Pictures of some polluted jetties (Offin and Ebutero).

\section{Sample Analysis}

The Colour of the sample was measured with the HI83200 multi-parameter photometer after filtering using Whatman No. 42 filter paper. The Conductivity, Turbidity, pH and Total Dissolved Solids (TDS) were measured using the Adwa conductivity meter, Hanna microprocessor turbidity meter, Beckman $350 \mathrm{pH}$ meter and HM digital TDS meter respectively. Temperature was measures at the jetties using $\mathrm{HM}$ digital thermometer. Biochemical Oxygen Demand (BOD) tests were carried out as described in APHA,(2012). Analysis of each of the selected chemical parameters was carried out with the use of Hach dr900 multi-parameter photometer. $10 \mathrm{ml}$ of the sample was dispensed into the cuvettes and chemical reagent for each parameter was added according to the manufacturer's specification. Results were read-off the Liquid Crystal Display of the photometer. 


\section{RESULTS AND DISCUSSION}

Table 1: Comparision of the Physicochemical parameters of water samples from some jetties in Lagos State with WHO/FMnev standards.

\begin{tabular}{|c|c|c|c|c|c|c|c|c|c|c|}
\hline PARAMETER & LEKKI & BAYEKU & OFFIN & ADDAX & FALOMO & METRO & ORIGIN & CMS & EBUTERO & $\begin{array}{l}\text { WHO/FMnev } \\
\text { STD(2003) }\end{array}$ \\
\hline Temperature $\left({ }^{0} \mathrm{C}\right)$ & $20.80 \pm 1.89$ & $20.10 \pm 1.15$ & $21.20 \pm 0.91$ & $22.90 \pm 2.05$ & $22.00 \pm 8.65$ & $21.60 \pm 5.77$ & $21.20 \pm 10.06$ & $21.70 \pm 10.21$ & $21.40 \pm 8.54$ & $20-30$ \\
\hline $\mathrm{Ph}$ & $6.92 \pm 2.15$ & $7.24 \pm 1.18$ & $7.34 \pm 1.09$ & $6.88 \pm 0.98$ & $7.10 \pm 2.19$ & $6.66 \pm 3.08$ & $6.90 \pm 2.00$ & $7.11 \pm 1.17$ & $6.66 \pm 1.04$ & $6.5-8.5$ \\
\hline Conductivity ( $\mu$ hoS/cm) & $1427 \pm 344$ & $196 \pm 54$ & $362 \pm 78$ & $3359 \pm 567$ & $4998 \pm 1458$ & $521 \pm 208$ & $425 \pm 154$ & $5646 \pm 1051$ & $4251 \pm 1705$ & 2000 \\
\hline Total Dissolved Solid (mg/l) & $317.00 \pm 111$ & $129.00 \pm 31$ & $194.00 \pm 23$ & $548.00 \pm 87$ & $699.00 \pm 67.21$ & $188.00 \pm 41.19$ & $125.00 \pm 89.55$ & $439.00 \pm 76.12$ & $446.00 \pm 101$ & 500 \\
\hline Colour (PtCo) & $34.00 \pm 9.11$ & $51.00 \pm 7.13$ & $75.00 \pm 21.77$ & $49.00 \pm 12.08$ & $15.00 \pm 3.77$ & $98.00 \pm 23.21$ & $71.00 \pm 16.09$ & $23.00 \pm 2.78$ & $20.00 \pm 1.81$ & 18 \\
\hline $\mathrm{DO}(\mathrm{mg} / \mathrm{l})$ & $7.68 \pm 0.81$ & $6.62 \pm 1.99$ & $7.99 \pm 0.76$ & $8.06 \pm 2.77$ & $7.86 \pm 0.67$ & $8.46 \pm 2.74$ & $8.21 \pm 2.08$ & $7.41 \pm 1.63$ & $6.28 \pm 1.19$ & 4.0 \\
\hline BOD (mg/l) & $155.00 \pm 77.01$ & $205.00 \pm 64.12$ & $214 \pm 51.89$ & $109 \pm 32.22$ & $142.00 \pm 48.01$ & $120.00 \pm 56.12$ & $98.00 \pm 23.45$ & $150.00 \pm 78.11$ & $100.00 \pm 46.09$ & 40 \\
\hline Nitrate $(\mathrm{mg} / \mathrm{l})$ & $5.2 \pm 1.17$ & $0 \pm 0.00$ & $4.2 \pm 1.34$ & $1.4 \pm 0.45$ & $0.3 \pm 0.07$ & $2.00 \pm 1.01$ & $0.3 \pm 0.02$ & $0.00 \pm 0.00$ & $0.00 \pm 0.00$ & 40 \\
\hline Cyanuric acid (mg/l) & $2 \pm 0.12$ & $2 \pm 0.11$ & $5 \pm 2.11$ & $2 \pm 0.31$ & $0.00 \pm 0.00$ & $4.00 \pm 1.50$ & $2.00 \pm 0.51$ & $1.00 \pm 0.02$ & $0.00 \pm 0.00$ & - \\
\hline Chrormium (mg/l) & $0.1 \pm 0.02$ & $0.00 \pm 0.00$ & $0.12 \pm 0.03$ & $0.07 \pm 0.01$ & $0.09 \pm 0.01$ & $0.06 \pm 0.01$ & $0.09 \pm 0.01$ & $0.08 \pm 0.01$ & $0.06 \pm 0.01$ & - \\
\hline Copper (mg/l) & $0.39 \pm 0.08$ & $0.54 \pm 0.28$ & $1.17 \pm 0.76$ & $0.33 \pm 0.00$ & $0.32 \pm 0.03$ & $0.98 \pm 0.15$ & $0.77 \pm 0.13$ & $0.39 \pm 0.8$ & $0.29 \pm 0.05$ & 0.3 \\
\hline Iron (mg/l) & $0.34 \pm 0.06$ & $0.69 \pm 0.19$ & $1.1 \pm 0.32$ & $0.55 \pm 0.08$ & $0.24 \pm 0.08$ & $0.81 \pm 0.27$ & $0.75 \pm 0.18$ & $0.22 \pm 0.07$ & $0.28 \pm 0.11$ & 1.0 \\
\hline Manganese(mg/l) & $0.45 \pm 0.05$ & $0.79 \pm 0.05$ & $0.41 \pm 0.03$ & $0.32 \pm 0.02$ & $0.01 \pm 0.00$ & $0.35 \pm 0.05$ & $0.66 \pm 0.05$ & $0.13 \pm 0.02$ & $0.09 \pm 0.02$ & 0.4 \\
\hline Sulphate(mg/l) & $35 \pm 15.11$ & $50 \pm 18.34$ & $65 \pm 22.71$ & $25 \pm 7.65$ & $25.00 \pm 7.65$ & $20.00 \pm 5.55$ & $45.00 \pm 15.98$ & $55.00 \pm 18.21$ & $55.00 \pm 18.21$ & 240 \\
\hline Phosphate (mg/l) & $0.09 \pm 0.01$ & $1.25 \pm 0.43$ & $1.25 \pm 0.55$ & $0.67 \pm 0.06$ & $1.11 \pm 0.07$ & $1.86 \pm 0.06$ & $0.33 \pm 0.01$ & $0.08 \pm 0.01$ & $0.17 \pm .01$ & 5 \\
\hline
\end{tabular}


The mean and standard deviation of the physicochemical parameters of water samples from the nine jetties are presented in Table 1. Also presented in Table 1 are the $\mathrm{WHO}(2003)$ guidelines for drinking water which are similar to FMnev (2003) standard values for comparision.

The metabolism of most aquatic organisms is catalysed by acids and bases which makes $\mathrm{pH}$ a major factor in all chemical reactions associated with formation, alteration and dissolution of mineral (Amaku and Akani, 2016; Yao and Byme, 2001). The pH of samples from all nine jetties studied range from 6.66 to 7.34 which conforms to the WHO standard limit of 6.5 to 8.5. This implies that effluents discharged into the jetties are mostly of organic nature (Phiri et al., 2005). The temperature of surface water determines the types of biological species present in the water and also their metabolism. Temperature range (20.10 to $\left.22.90^{\circ} \mathrm{C}\right)$ observed at all jetties considered in this study was within the limits stipulated by FMnev(2003).

Water samples from Addax $(3359 \mu \mathrm{hoS} / \mathrm{cm})$, Falomo (4998 $\mu \mathrm{hoS} / \mathrm{cm})$, CMS (5646 $\mu \mathrm{hoS} / \mathrm{cm})$ and Ebutero (4251 $\mu \mathrm{hoS} / \mathrm{cm})$ had conductivity values higher than the stipulated standard value of $2000 \mu \mathrm{hoS} / \mathrm{cm}$. Conductivity is the ability of a medium to conduct electricity with respect to the total ionized constituents in the medium. These jetties are in the urban area where lots of activities such as cooking and selling food and drinks, fish processing, unauthorized waste disposal and washing are carried out. It is expected that high levels of inorganic ions will be in solution at these locations. Total Dissolved Solids (TDS) at these same locations: Addax $(548 \mathrm{mg} / \mathrm{l})$ and Falomo $(699 \mathrm{mg} / \mathrm{l})$ also exceeded the standard limit for TDS $(500 \mathrm{mg} / \mathrm{l})$. TDS value describes the amount of inorganic salts and organic matter present in solution in water (Aina and Oshunrinade, 2016).

The values of colour of the water samples from eight out of the nine jetties studied exceeded the standard limit of 18PtCo with the highest value of 98PtCo observed at Metro jetty and the least value of $15 \mathrm{PtCo}$, which conformed to standard, was obtained at Falomo jetty. Colour in water is due to the presence of coloured organic substances, metals such as iron, manganese and copper or the presence of highly coloured industrial wastes (Adeniran et al, 2013).

Dissolved oxygen values of water samples from all nine jetties conform to the stipulated standard limit of $\mathrm{WHO}(>4.0 \mathrm{mg} / \mathrm{l})$. Thus implying that enough oxygen is available in the water at these jetties to sustain aquatic life. The presence of free (dissolved) oxygen in water is an indication of the ability of that water body to support biological life (Adeniran et al, 2012). The sufficient dissolved oxygen at these jetties could be attributed to the fact that waste dumped around these jetties are inorganic; most of which cannot undergo biodegradation such as polythene bags, plastic bottles, food packs, metals etc as shown in Figure 1. Biochemocal Oxygen Demand (BOD) is a measure of the amount of oxygen consumed by microorganisms in decomposing organic matter in waste water. BOD (100 to $205 \mathrm{mg} / \mathrm{l}$ ) obtained for all samples in this study exceeded the standard values $(40 \mathrm{mg} / \mathrm{l})$. this result correlates with findings of Patra et al.,(2009) where it was observed that BOD values at shore is often always high because of the influence of human settlements and mixing of untreated sewage.

The chemical parameters considered in this study are Nitrate, Cyanuric acid, Chromium, Copper, Iron, Manganese, Sulphate and Phosphate. Nitrate, Sulphate and Phosphate values obtained from all nine jetties conform to the stipulated standard as shown in Table 1. Iron value at Offin jetty $(1.1 \mathrm{mg} / \mathrm{l})$ and Manganese value at Lekki(0.45mg/l), Bayeku(0.79mg/l), Offin $(0.41 \mathrm{mg} / \mathrm{l})$ and Origin $(0.66 \mathrm{mg} / \mathrm{l})$ exceded the standard limit of $1.0 \mathrm{mg} / \mathrm{l}$ for Iron and $0.4 \mathrm{mg} / \mathrm{l}$ for Manganese. Copper value at Ebutero $(0.29 \mathrm{mg} / \mathrm{l})$ conformed to WHO standard, values at other jetties ranged between $0.32-1.17 \mathrm{mg} / \mathrm{l}$. The presence of these parameters in water bodies is not desirable at high quantities although they also serve as nutrients to aquatic plants and animals; for instance, high amounts of nitrogen supports eutrophication where excessive plant growth is experienced resulting in rapid depletion of dissolved oxygen in the water and reducing the ability of the water bodies to support biological life. The presence of iron in water gives brown colouration and causes rusting of metal components of marine transport. High values of Manganese also gives colour to the water thus affecting the aesthetics of such water bodies.

\section{CONCLUSION}

This research was carried out to evaluate the physicochemical properties of water samples from various jetties from Ikorodu to Lagos Island, Lagos State in comparision to WHO/FMnev standards. It can be concluded that most physicochemical parameters at most of these jetties conform to the WHO/FMnev standards. However, Biochemical Oxygen Demand (BOD) and colour of all jetties studied exceeded the statutory limits, Conductivity at Addax, Falomo, CMS and Ebutero and TDS at Lekki, Addax, Falomo, CMS and Ebutero also exceeded stipulated standards. Copper value of all jetties except Ebutero, Iron at Offin and Manganese at Lekki, Bayeku, Offin and Origin also exceeded WHO/FMnev standards. It is therefore recommended that proper solid and liquid waste collection facilities should be made available at these jetties to curb the indiscriminate act of improper waste disposal. Further work will be carried out on the microbiological quality of marine water at these jetties.

\section{ACKNOWLEDGEMENT}

I acknowledge the assistance of Mr Oshikoya Adesekeji of the Institute of Maritime Studies, University of Lagos for collecting the samples used for this study.

\section{REFERNCES}

Adeniran, A. E., Aina, A. T., Oshunrinade, O. O and Oyelowo, M. A., 2012. Assessment of the efficiency of Constructed Wetland in Domestic Waste water Treatment at the University of Lagos, Nigeria. J. Sust. Devt. Envtal. Protect. 2(2):

Adeniran, A. E., Aina, A. T and Oshunrinade, O. O., 2013. Investigation of Reclaimed Effluent water from a Constructed Wetland Domestic Sewage 
Treatment Plant as additional source of Raw water at the University of Lagos, Nigeria. Int. J.Envtal. Sci.Toxicol. 1(1):

Aina, A. T and Oshunrinade, O. O., 2016. Comparision of Water quality from Boreholes and Hand-dug wells around and within the University of Lagos, Akoka, Lagos State. Int.J.Res. Envtal Stud. 3(2):93-100

Amaeze, N. H., Egonmwan, R. I., Jolaosho, A. F and Otitoloju, A. A., 2012. Coastal Environmental Pollution and Fish Species Diversity in Lagos Lagoon, Nigeria. IJEP 2 (11):8-16.

Amaku, G. E and Akani, N. P., 2016. Physicochemical Properties of the Effluents of Forcados Terminal in Warri, Delta State. Journal of Environmental Chemistry and Ecotoxicology 8(2): 9-13

APHA (American Public Health Association). 2012. Standard Methods for the Examination of Water and Wastewater. $22^{\text {nd }}$ Edition. Washington DC USA.

Federal Ministry of Environment (FMnev) Guidelines and Standards. 2003. Abuja, Nigeria.

Lagos State Government. 2016. The Secretariat, Obafemi Awolowo Way, Ikeja, Lagos State, info@lagosstate.gov.ng

Okoye, C. O., Onwuka, S. U and Obiakor, M. O., 2010 Pollution survey in the Lagos lagoon and its environmental consequences. Tropical Built Environment Journal 1(1): 41-57
Patra, A. K., Acharya, B. C and Mohapatra, A., 2009. Occurrence and Distribution of Bacterial Indicators and Pathogens in Coastal Waters of Orissa. Indian Journal of Marine Sciences 38(4):474-480.

Phiri. O. P., Moyo, B. H. Z and Kadewa, W., 2005. Assessment of the Impact of Industrial effluents areas of Malawi. Int. J. Envtal Sci. 2(3): 237244.

WHO., 2003. Revision of WHO guidelines for Drinking water Quality. Bilthocat. The Netherlands, 2-10.

Yao, W and Byme, R. H., 2001. Spectrophotometric determination of Fresh water $\mathrm{pH}$ using Bromocresol purple and Phenol red. Environ. Sci. Technol. 35:1197-1200. 